\title{
Human potential as a strategic resource of the Russian Arctic sustainable development
}

\author{
Y. Bolsunovskaya ${ }^{\text {la }}$, A. Sentsov ${ }^{2}$ \\ ${ }^{1}$ Tomsk Polytechnic University, 634050 Lenin Avenue, 30, Tomsk, Russia \\ ${ }^{2}$ Tomsk State University, 634050 Lenin Avenue, 36, Tomsk, Russia
}

\begin{abstract}
Efficiency of the Russian Arctic development depends greatly on human potential of the population inhabiting and conducting work activities in the Arctic regions. Human development is a key factor facilitating sustainable development of the area. Nowadays, there are negative social tendencies in the Russian Arctic, which does not ensure social safety of the population. It necessitates revision of the existing legal standards and development of a target-oriented federal policy that would take into account Arctic indigenous peoples' interests and enhance the attraction of workforce from other regions. The paper covers basic social problems of the Russian Arctic and offers some ways to solve them. The author considers the human potential as a strategic resource for sustainable development of the region. Therefore, the human potential should remain the focus of government's attention and undergo regular assessment.
\end{abstract}

\section{Introduction}

The world's nations presume that sustainable development is an appropriate response to the danger of globalization [1]. Sustainable development is the development «which meets the needs of current generations without compromising the ability of future generations to meet their own needs» [2].

The specific geographical and climatic conditions of the Arctic present a challenge to economic activity in the region. In fact, it is these conditions that restrain geophysical exploration of the Arctic continental shelf. Besides, they make higher demand on communicationsinfrastructure availability, programs aimed at preserving and protecting the Arctic environment and unique ecosystems, sustainable development of social systems and staff resources trained specifically to work under Arctic conditions.

Nowadays, effective development of the Russian Arctic is impeded by negative social tendencies apart from an array of economic, political and environmental challenges. These negative tendencies are manifested through qualitative and quantitative indices of human potential, loss of population for other regions, morbidity increase related to climate change, low quality of life, lack of highly qualified staff, out-of-date social infrastructure, vulnerability of indigenous communities, etc. All these factors require developing a target-oriented state social policy.

The specific character of the northern Arctic regions involves unique human potential with a peculiar ethnic structure that is conditioned by social functioning of the indigenous communities. The Russian Arctic indigenous communities have unique social, cultural and environmental heritage. The necessity for these communities to be involved into political, economic and social processes sets new objectives for the state to determine the development prospects in modern geopolitical conditions $[3,4]$. One of the key tasks of national social policy in the region is to ensure social safety of the population in the Arctic regions of Russia.

Social safety as a base of the Arctic social policy is a condition that allows each person, family, and social group to reach their full potential, contributing to sustainable development of the Russian Arctic. Thus, the human resource of the Russian Arctic is a strategic resource that promotes the solution of important social and economic tasks of long-term sustainable development of the region.

\section{Materials and methods}

Social safety of the Russian Arctic can be ensured by target-oriented social policy and systemic interventions of the state, agents of Petroleum industry and society. The research outcomes are characteristics of social structure of the Arctic population, consideration of the basic social problems impeding sustainable development of the region.

The information database of the research consists of publications, standard-setting documents, and state statistical database.

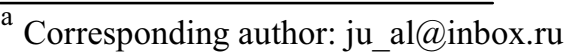




\section{Results and discussion}

The Arctic zone of the RF is a macro region that borders with the Arctic Ocean and includes the territories of tundra and forest-tundra, islands and archipelagoes, offshore zones located within a 200-mile economic zone of the country. Russian Arctic holds most of hydrocarbon and mineral resources and has a huge economic potential to serve the needs of Russian economy on a long-term basis. The development of the High North and Arctic shelf hydrocarbon and mineral resources and exploitation of the Northern Sea Route are the priority projects for Russian Arctic development. To implement these projects, it is essential to resolve a number of tasks, precisely, to contribute to economic, social, scientific, and transport-related infrastructure development and other [5].

Among all Arctic nations, Russian Arctic zone is the biggest one occupying about 9 million $\mathrm{km}^{2}$ and having a maximum marine borders stretch. The Arctic Russian zone embraces the following regions: the Murmansk region, the Arkhangelsk Region (including such city districts as Arkhangelsk, Severodvinsk, Novodvinsk, Primorsky, Mezensky, and Onezhsky municipal districts and arctic islands), the Komi Republic (Vorkuta), the Nenets Autonomous District, the Yamalo-Nenets Autonomous District, the Republic of Sakha Yakutia (Allakhovsky, Anabarsky, Bulunsky, Nizhnekolymsky, and Ust'-Yansky regions), the Krasnoyarsk Krai (Norilsk city district, Taimyr Dolgano-Nenets municipal district, Turukhansky region), the Chukotka Autonomous District.

In comparison with other Artic nations, Russia holds the largest human population in the Arctic. According to the data $\left(1^{\text {st }}\right.$ January, 2015, table 1$)$, population in Russian Arctic zone accounted for 2.3 million, i.e. 1.6\% of total population of the RF and $40 \%$ of total population of the whole Arctic region.

Table 1. Evaluation of the Arctic land resident population of the Russian Federation

\begin{tabular}{|l|c|c|}
\hline $\begin{array}{l}\text { Populated Arctic } \\
\text { territories } \\
\text { (Russian } \\
\text { Federation) }\end{array}$ & \multicolumn{2}{|c|}{ Population (persons) } \\
\cline { 2 - 3 } & $\begin{array}{c}\mathbf{1}^{\text {st }} \text { January, } \\
\mathbf{2 0 1 4}\end{array}$ & $\begin{array}{c}\text { 1st January, } \\
\mathbf{2 0 1 5}\end{array}$ \\
\hline $\begin{array}{l}\text { The Komi } \\
\text { Republic }\end{array}$ & 84707 & 82953 \\
\hline $\begin{array}{l}\text { The Republic of } \\
\text { Sakha Yakutia }\end{array}$ & 26447 & 26194 \\
\hline $\begin{array}{l}\text { The Krasnoyarsk } \\
\text { Krai }\end{array}$ & 228493 & 227205 \\
\hline $\begin{array}{l}\text { The Arkhangelsk } \\
\text { Region } \\
\text { (excluding the }\end{array}$ & 656624 & 655100 \\
$\begin{array}{l}\text { Nenets } \\
\text { Autonomous } \\
\text { District) }\end{array}$ & 771058 & 766281 \\
\hline $\begin{array}{l}\text { The Murmansk } \\
\text { region }\end{array}$ & 43025 & 43373 \\
\hline $\begin{array}{l}\text { The Nenets } \\
\text { Autonomous } \\
\text { District }\end{array}$ & 50555 & 50540 \\
\hline The Chukotka & & \\
\hline
\end{tabular}

\begin{tabular}{|l|c|c|}
\hline $\begin{array}{l}\text { Autonomous } \\
\text { District }\end{array}$ & & \\
\hline $\begin{array}{l}\text { The Yamalo- } \\
\text { Nenets } \\
\text { Autonomous } \\
\text { District }\end{array}$ & 539671 & 539985 \\
\hline Total & & \\
\hline
\end{tabular}

The most populated regions of the RF are as follows: the Arkhangelsk Region (27.4\%), the Murmansk region (32.0\%), and the Yamalo-Nenets Autonomous District $(22.6 \%)$ (table 2).

Table 2. Evaluation of the Arctic land resident population of the Russian Federation (percentage, \%)

\begin{tabular}{|l|r|r|}
\hline Populated Arctic & \multicolumn{2}{|c|}{ Population (\%) } \\
\cline { 2 - 3 } $\begin{array}{l}\text { Ferritories (Russian } \\
\text { Federation) }\end{array}$ & $\mathbf{1}^{\text {st }}$ Jan., 2014 & 1st Jan., 2015 \\
\hline The Komi Republic & 3,529 & 3,468 \\
\hline $\begin{array}{l}\text { The Republic of Sakha } \\
\text { Yakutia }\end{array}$ & 1,102 & 1,095 \\
\hline The Krasnoyarsk Krai & 9,518 & 9,500 \\
\hline $\begin{array}{l}\text { The Arkhangelsk Region } \\
\text { (excluding the Nenets } \\
\text { Autonomous District) }\end{array}$ & 27,353 & 27,391 \\
\hline The Murmansk region & 32,120 & 32,040 \\
\hline $\begin{array}{l}\text { The Nenets Autonomous } \\
\text { District }\end{array}$ & 1,792 & 1,814 \\
\hline $\begin{array}{l}\text { The Chukotka } \\
\text { Autonomous District }\end{array}$ & 2,106 & 2,113 \\
\hline $\begin{array}{l}\text { The Yamalo-Nenets } \\
\text { Autonomous District }\end{array}$ & 22,481 & 22,578 \\
\hline
\end{tabular}

Such enormous human resources necessitate the development of favorable working environment and living conditions. It would allow nurturing human potential as a key criterion of social balance and sustainable development of the Arctic region. The concept of sustainable development is referred to achieving overall balance between social, economic, and environmental aspects. The social aspect in this case implies social stability in all existing cultural systems, equitable distribution of natural resources among all members of society, preservation and development of human and cultural potential [5].

Today, geopolitical interests of Russia in the Arctic are in direct conflict with the existing trends in the Arctic region development. This conflict is manifested through the following social problems:

1.Involvement of indigenous small ethnic communities into sustainable development of the Arctic region

Being dependent on natural resources, Arctic communities and indigenous peoples have an extensive knowledge and experience in adapting to rapidlychanging ecosystems, which allows them to take advantage from biophysical and social changes. Their expertise in climate change and recommendations on minimizing its negative impact on the whole world are of unique value. However, traditional way of indigenous peoples' life can hardly be secured within the areas targeted for natural resources development. Therefore, maintaining a high level of biodiversity and productivity of farming and hunting areas is the main condition to 
preserve their culture and way of life. It means that local indigenous peoples can easily adapt to modern conditions of the Arctic region development only if there is an adequate legal regulation.

Today, natural resources development within the indigenous peoples' territories leads to disturbance of their traditional way of life. The Russian legislation system does not provide clear requirements to evaluate the impact of industrial development in the Arctic on the traditional way of life of the local communities, as well as it does not involve any adequate mechanism for the recovery of damages for disturbance of the traditional nature use. Thus, indigenous peoples' rights remain inadequately protected. Despite this fact, it is worth noting that Russian companies are committed to working in accordance with the international standards, which, in its turn, forces them to comply with the obligations concerning indigenous peoples. However, the fact that the terms of license agreement on engagement with indigenous peoples are rarely specified before bid issuance date generates various conflicts and creates additional difficulties for both sides.

Protection of indigenous peoples' interests depends directly on effective interaction with the government. According to the data of the Russian Association of Indigenous Peoples of the North in 2014 [6] the following key problems of indigenous peoples and government interaction were distinguished:

- absence of procedure in definition of nationality;

- a limited list of the traditional economic activities;

- lack of legal regulation in territory formation procedure of federal traditional natural resource use etc.

Therefore, at present the impact of political and economic factors has limited the possibilities of indigenous peoples' full participation in sustainable development activities of the Arctic territory.

2.Problems of indigenous and non-indigenous population' adaptation

The culture of local communities is based on the close relationship of people with nature, which could be preserved only in case of well-balanced use of biological resources. However, the rapid warming trend and consequences of industrial activity in this region significantly reduce the possibility of on-time adaptation of local communities to ongoing changes threatening their traditional lifestyle. Such factors as landscape continuity, maintenance of the traditional biodiversity of the Arctic region are obligatory conditions for indigenous peoples' well-being. The culture of local communities is based on the close relationship of people with nature which could be preserved only in case of well-balanced use of biological resources.

The intensification of natural resource development has led to the increase in migratory flows to the extreme North regions. It presents certain challenges for both indigenous and non-indigenous population. These challenges are conditioned by the two major factors. Firstly, migration from familiar climatic conditions to extreme ones results in development of negative conditions and syndromes. The negative conditions include: seasonal mood disorders, vitamin deficiency, reproductive disorders etc. Among the negative syndromes there are the following: polar stress syndrome (the North biological phenomenon), polar metabolic type (transition from carbohydrate to fat metabolism), polar short breathing, premature ageing, etc [7]. The conditions and syndromes outlined are mostly typical for migrated population, whose adaptation takes rather a long time period. The working conditions in the North are characterized by intense acclimatization and psychological strains. Within the adaptation period some steady specific states can be developed in the nonindigenous people. These states are explained by the combined impact of different natural and climatic factors on human organism.

Secondly, the rate of adaptation to the new environmental conditions is defined by community and a person's relationship with it. In Arctic conditions the requirements for adaptation mechanisms grow due to specific natural and living conditions. The existing wage differentials, deprivation of indigenous peoples' rights, low level of culture in international communication, nationality-based privileges have produced tension in relationship of indigenous and migrated population.

3. Lack of highly-qualified staff

Over a long period of time Russian Arctic represents a territory of intensive research and economic activity. In addition, the growing changes in perception of geographical role of Russian Arctic increase the need for training of highly-qualified professionals capable of developing social capacity and participating in the sustainable development of the region. The geographical characteristics of Russian Arctic condition the demand for human resources having specific features and competencies. But nowadays, training highly-qualified polar explorers is accompanied by the following challenges:

- remoteness of the region and field sites from the main training centers;

- high cost of infrastructure and research-educational projects in the Arctic region;

- underdevelopment of research-production and education infrastructure (research institutions, grounds, facilities and up-to-date research manuals);

- uneven distribution of intellectual and infrastructure resources among the training centers;

- absence of network national research-educational programs in specialists' training for Arctic and think tanks for assessing the quality of educational programs;

- low academic mobility of students, young scientists and demand in Arctic occupations among the youth;

- gender imbalance in the workforce (maledominated professions are in demand);

- inefficient use of retired armed service and navy personnel, since there is no vocational retraining for retired military men with higher technical education;

- inadequate institutional environment, coexistence of different lifestyles (post-industrial, industrial and preindustrial);

- poor workforce mobility. 
The attractiveness of the Arctic zones in terms of natural resources leads to the demand in highly-qualified personnel. Workforce development within the region is connected with tackling the issues of personnel settlement and new workforce attraction and is currently hindered by imperfect legislation and educational system, severe natural conditions, and hard adaptation to regional changes.

4. Healthcare for remote communities in the Arctic

It is a challenge for nomadic peoples to get to hospital and more often than not, they fail to receive even therapeutic care. However, the sickness level within the region is high due to severe natural conditions and climatic changes [8], everyday challenges, and negative environmental impact. There are growing risks for the health of northern peoples: increase in morbidity and mortality resulting from anomalous high/low temperatures, increased accidents of injury and mortality caused by unpredictable weather conditions (storms, floods, etc.), growing number of infectious, parasitic diseases and cancer, acute and chronic illnesses, reproductive dysfunction $[9,10]$.

\section{Conclusion}

The challenges mentioned above indicate social imbalance in Russian Arctic. However, it is for social balance to mitigate the effects of political, economic, and legal changes, secure social safety and high living standard. The long-term national policy should be focused on cooperation between all Arctic natural resource users and securing local communities through:

1) establishing administrative areas of traditional natural resource use;

2) preferential treatment for traditional economic complexes supporting indigenous peoples living;

3) implementing laws and regulations to fix indigenous peoples' rights and ensure their involvement in making decisions at all levels;

4) ensuring indigenous peoples training to increase their competitiveness on the local labor market;

5) improving health care;

6) expanding the scope of cooperation between the departments and different parties concerned at all levels.

The key issue is the controversy between the significance of Russian Arctic natural resources in terms of geopolitics and national economy and social issues in the region. The expected Arctic resource potential prompts to develop a social security system, which would consider the negative impact of such social issues. Considering geopolitical importance of Russian Arctic, it is necessary to make a shift from natural resources exploitation to human capital development and secure social safety for the Arctic land resident population of the Russian Federation.

\section{References}

1. Th. Kerr, Humanities Graduate Research Conference (2008)
2. Resource efficiency: What does it mean and why is it relevant?

https://www.ecn.nl/docs/library/report/2013/o13004.pdf (2013)

3. Y. Bolsunovskaya, G. Boyarko, L. Bolsunovskaya, IOP Conf. Ser. 21 (2014)

4. Or. Young, Ambio 41, 1 (2012)

5. Y. Bolsunovskaya, L. Bolsunovskaya, A. Sentsov, N. Scherbinina, IOP Conf. Ser. 27 (2015)

6. Report of the Association of Indigenous Peoples of the North, Siberia and Far East of the Russian Federation, Indigenous Peoples' World, Arctic Alive 30 (2014).

7. Scientific and Technical Issues of Arctic Development (Nauka, 2015).

8. N. Shakhova, I. Semiletov, A. Salyuk, V. Yusupov, D. Kosmach, O. Gustafsson, Nature Geoscience 7 (2013)

9. B. Revich, et al. The United Nations Office in Russia Arctic Initiative http://www.unrussia.ru/sites/default/files/doc/Arcticeng.pdf (2008)

10. J. P. Dudley, E. P. Hoberg, E. J. Jenkins, A. J. Parkinson, EcoHealth, 12, 2 (2015) 